\title{
Thai Kindergarten Students' Thinking and Communicating Skills: Using Innovation on Texts in Gifts from a Snail
}

\author{
Sukhuma Akarum \\ KKU Demonstration Kindergarten School, Khon Kaen, Thailand \\ Ladda Chiangnangam \\ KKU Demonstration Kindergarten School, Khon Kaen, Thailand \\ Chokchai Yuenyong* \\ Faculty of Education, KhonKaen University, Khon Kaen, Thailand \\ Email: ychok@kku.ac.th \\ Suwaree Sivabhaedya \\ Faculty of Education, KhonKaen University, KhonKaen, Thailand
}

Doi:10.5901/mjss.2015.v6n3s1p119

\section{Abstract}

The paper shares the ways in which kindergarten students' thinking and communicating were apparent while innovating on the text of a story called Gifts from a snail. The participants included 43 kindergarten students who attended KKU Kindergarten Demonstration School, Thailand. The children were first read the story and then were asked to innovate on the text when the teacher asked them if they were a snail what gifts would they prepare for an angel. The students' were asked to draw a picture of their suggested gift and present their ideas and justifications to the group. The pictures were categorized in order to explain the children's ideas and thus their communication and thinking skills.

Keywords: text innovation, kindergarten, thinking, communicating

\section{Introduction}

The goal of kindergarten education in Thailand aims to support children's development of body, mind, emotion, and intellectual skills. These aims included having a healthy body; healthy mind and being happy, being ethical with high standards of moral behaviour and also appreciating art, music, movement, and exercise. Further it involves having the ability to work independently; love and preserve nature, the environment, and culture and also to be respectful and promote Thai identity. Theability to communicate; thinking skills and solving problems; imagination and creativity; and positive attitude toward learning and inquiring are also very important goals (MOE, 2003).

Although today's early childhood educators often focus on enhancing reading and mathematics skills to meet ever increasing academic expectations, we must also remain committed to promoting broader thinking abilities. Three to five year children are developing their bodies and brains. They should have chance to learn and inquire through playing, experimenting, discovering, communicating, decision making, problem solving and creative thinking. Parents and teachers, therefore, have a responsibility to provide them these experiences and activities in order to prepare children to be successful in their future study (MOE, 2003). Key conceptsinvolved in each domain of preschool learning must go hand in handwith information and skill acquisition. Official documents cite research showing that metacognition-higherlevel thinking and problem-solving skills-develops when children are encouraged to reflect, predict, question, and hypothesize. Thus it becomes important for us as teachers to ask; How can adults help children exercisethese capabilities?There is empirical and practical evidence to suggest that teachers can promote thedevelopment of thinking and reasoning in young children in the earlyyears by providing two important skills-planning andreflection. Both are thoughtful activities that encourage children toconsider what they are doing and what they are learning. We can alsopromote a broad range of other academic, social, and artistic competencies (Epstein, 2003).

This paper aims to report one way in which we attempted to do this by providing a context for children to innovate on a text in a story about Gifts for a snail. We wanted to use the story to encourage planning and reflection in a creative way. 


\section{Methodology}

This research is conducted regarding the interpretive paradigm. Interpretive research seeks to describe and interpret human behaviour based on their natural setting rather than form laws about it (Marriam, 1998; Cohen et al., 2000). Concerning the issue of dependability, therefore, a clear description of how data was obtained and open acknowledge of context should be taken into account. This study aim to interpret kindergarten students' thinking and communicating skills through their drawing and conversation interview while innovating on the text of a story called Gifts from a snail.

\subsection{Participants}

The participants in this intact classroom were 43 kindergarten students from KKU Demonstration Kindergarten School, KhonKaen, Thailand.

\subsection{Text Innovation with Gifts from a Snail}

Teacher told students the story of "Gifts from a Snail". The story began as the scene of animals havea meeting to decide what would be a good gift for the angel's birthday.

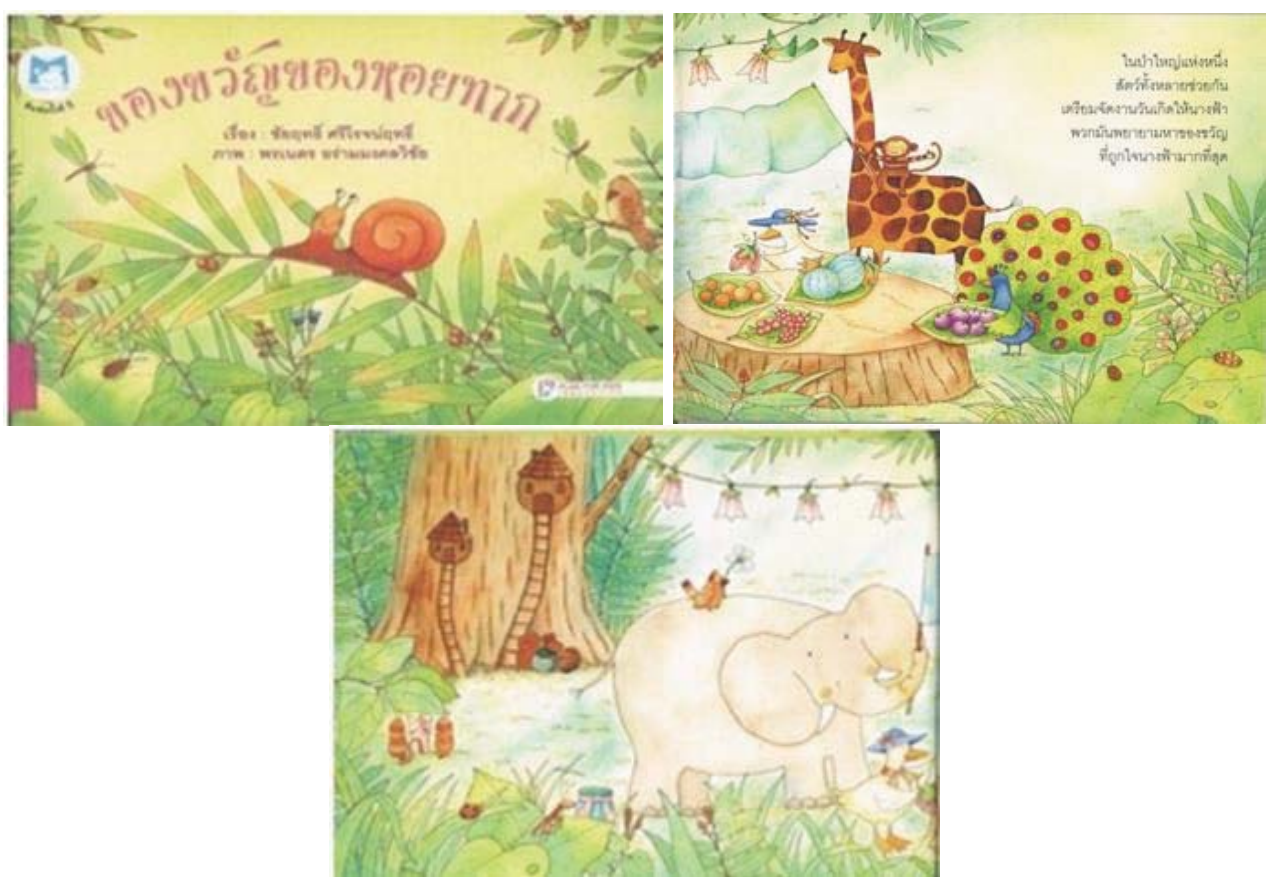

The giraffe, zebra, swan, and birds have already selected their own gifts to give to the angel. Each animal tried to claim that theirswas the best gift by giving reasons for their choice. However, a snail could not think of any gifts for the angel. The snail walked deep into the forest to think about what his gift should be.
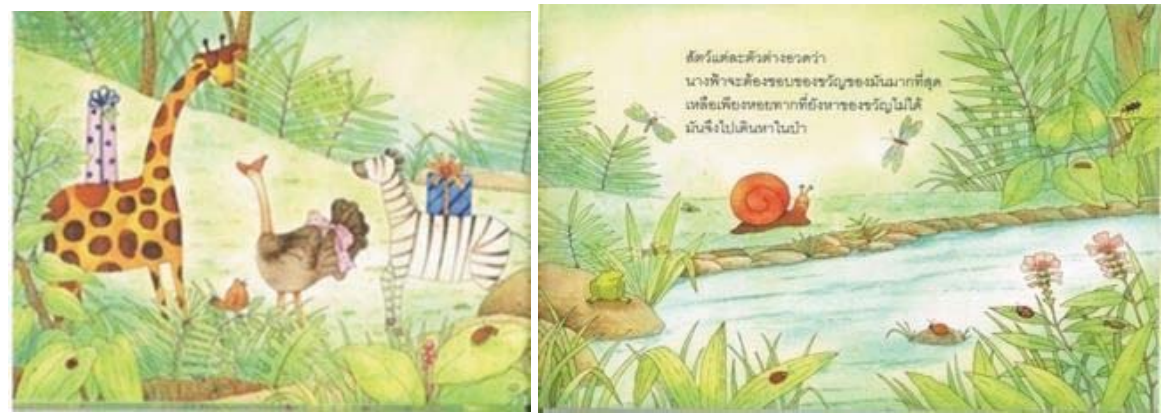
On the way, snail met the peacock. The peacock showed snail the beautiful feather which he might have as a gift. Then, the snail met the cow. The cow showed snail fresh milk which she suggested could also be a gift saying that the angel may like the milk. And, then the snail met army of ants. The ants told snail that they provided sweet sugar to make the candy. "The angel probably like the candy"the ant said.
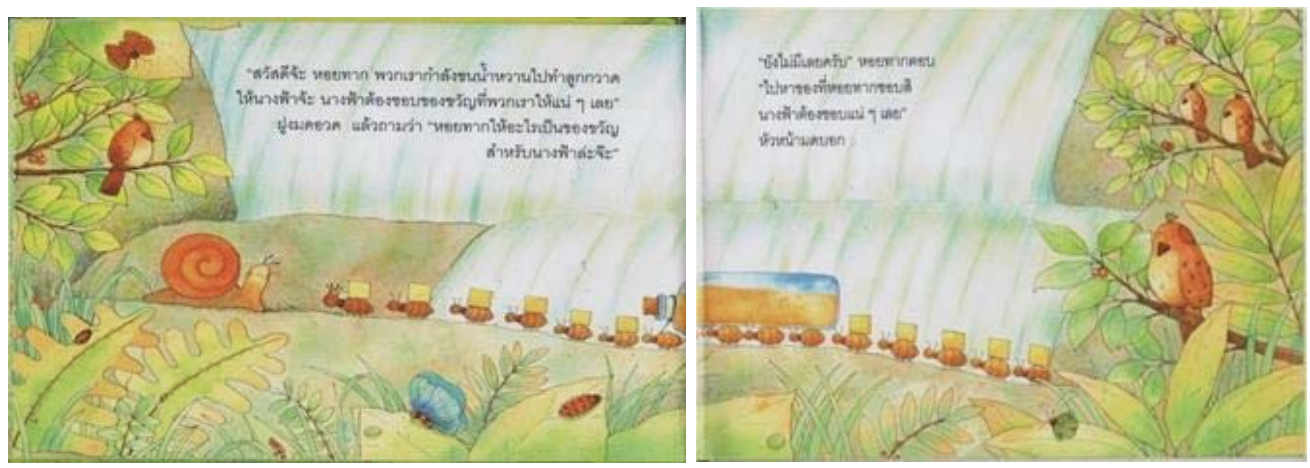

After the students heard about the possible and various gifts from each of the animals, the teacher asked students if they were the snail what they might give the angel. This question allowed students to start planning what the gift might be. They drew pictures to communicate their decision. Then, teachers asked students to explain their ideas about the gifts.

\subsection{Data analysis}

Pictures and students' explanation were categorized. Each category was explained and interpreted to show what and how they planned. And, then, the category was reviewed and re-categorized. Students' reflection about their planning was interpreted. Students' reasoning represented what and how they understand the story, using their language and communicating, and the choice of gift reflected them critically thinking about the nature of the gift.

\section{Findings}

Most of the students could communicate their choice as indicated in their drawing. Students' reflections about what they planned to give the angelrevealed that they were able to take the position of others as well as state their own personal preferences for a gift, and also that they were able to be metacognitive in the process. They were able to state what they know and think and share it with others. The students' reflection of their planning could be categorized into two categories. This included 1) communicating their planning without linking to the story telling, and 2) communicating their planning with linking to the story. The majority of students could communicate their planning without linking to the story telling as in Table 1.

Table 1: Category of students' thinking and communicating in Text innovation

\begin{tabular}{lcc}
\hline Category & Frequency (students) & Percentages \\
\hline Communicating their planning with linking to the story telling & 24 & 55.81 \\
Communicating their planning with linking to the story telling & 19 & 44.19 \\
\hline
\end{tabular}

\subsection{Communicating their planning without linking to the storytelling}

This category showed that students could communicate their planning but they did this from their own perspective not according to the story that was being used in this instance. It seemed that their ideas based on egocentric viewpoints. They think they are going to have the gift so chose what they thought would be a good one. For example - they mentioned "I like..., I want..." so presumed the angel would want it as well. However, they definitely know what they think they want and were able to communicate this effectively in detail. For example,they could explain the size and the weight of the item and describe it effectively. They explained how they have personal experiences related to the suggested gifts such as how they thought a song was funny, or that they had enjoyed a particularly impressive activity, or loved a special birthday cake. 
This could be seen as example of students' communicating and thinking (Thanaporn and Thitiphong). Thanaporn planned to give the box of present as showed in the Figure 1. She drew the carrot outside the present box. She reflected that "she think the angel may like the carrot". Then, she explained how to cook Carrot Fritter. She said "we have to put the carrot into the dish of flour, and then fry it". It seemed that she drew carrot outside the present box in order to communicate something inside. She explained how to cook the carrot because she experiences cooking the carrot. So, she explained what she knew rather than what reason.

Figure 1: Thanaporn communicating

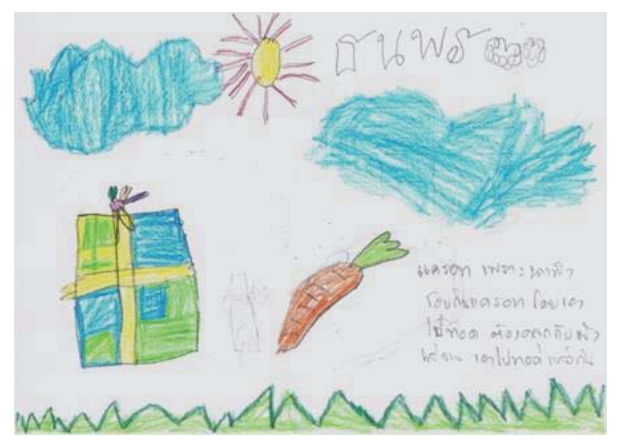

Thitiphong informed that "it is the present box that he prepares for the angel as showed in Figure 2. It is very big". He drew many things inside the box. It seemed that he drew himself beside the box in order to communicate how the big box is. He quite has his strategy to explain the size. He thinks that once the angel see the big box, she will be exciting. However, the things inside could be categorized into group - first is things for angel and another is things for himself.

Figure 2: Thitiphong's communicating

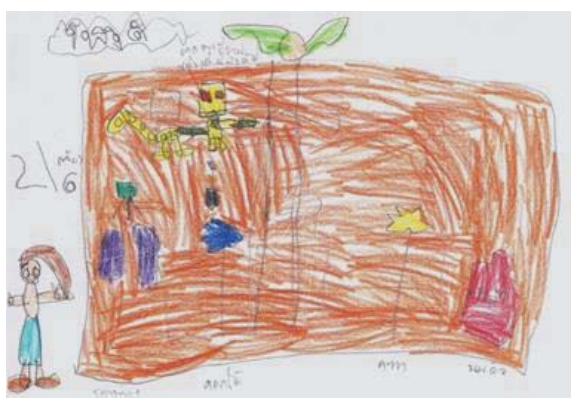

\subsection{Communicating their planning and linking to the story}

This category showed that students can communicate what they plan. Their reflections showed their understanding of the story because they remembered that the gifts should be prepared for the angel and not for themselves. Their drawings and reflections also showed how they well they could communicate and their high level of imagination. They explained what kinds of gifts might be an angel's favorite gifts, how they are useful for the angel. The colors of gifts were even considered. This could be seen as example of students' communicating and thinking (Saranyakon and Chalisa).

Figure 3: Saranyakorn communicating

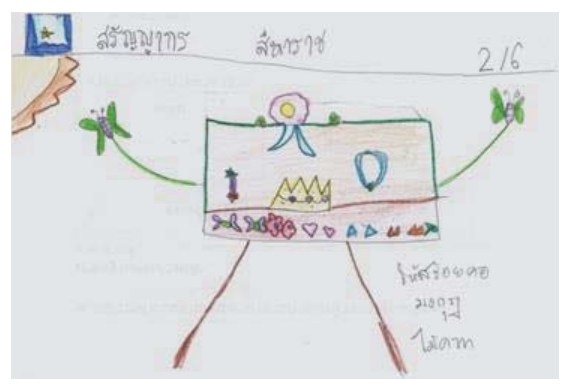


Saranyakon, she will give the angel the necklace, crow, magic stick. It seemed that she consider the things appropriate for angel as beautiful and powerful lady. And, she drew the butterfly to bring the crow for the angel. The angel and butterfly are two things that come from another story.

Chalisa will give the angel the magic stick and make up set. She prepares the things that the angel need. Imagine how the snail could find these things. Only human Chalisa could find them. However, she knows and aware of preparing the gift for angle because she drew the present box and concerning on angel need.

Figure 4: Chalisa communicating

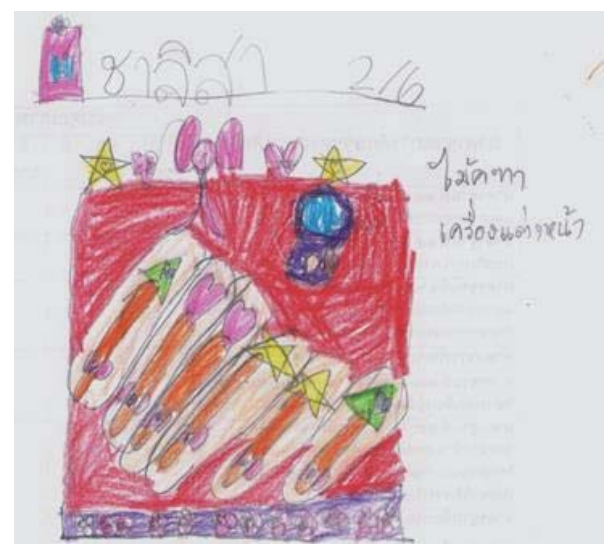

\section{Conclusions}

Innovating on text is a useful way to start introducing students to books and stories with opportunities to engage with being creative and using thinking and planning skills. It accompanies general literacy lesson in which a book is readaloud, shared, or used in a guided reading experience.The text innovation of Gifts from a snail allowed students to think and communicate what they think. It indicated that students could communicate their ideas even though they could not use the language in its written form. They used visual and oral literacy skills to communicate their ideas and these were careful and either linked to the story or their own personal preferences. The pictures that they drew also represent what they were able to plan and their ideas. They gave specific details about size and weight to show that they have a detailed knowledge of the objects that they chose. They knew what themselves and others might have as favorite things. When using innovation on text as an experience, students provided their ideas within the structure of their own language and if allowed them to do this. The activity provided a context communication and metacognition and was useful for idea generation.

\section{References}

Cohen, L., Manion, L. and Morrison, K. (2000). Research Methods in Education. London, UK: Routledge Falmer. Epstein, A.S., (2003) How planning and reflection develop young children thinking skills. Young Children, September, 28 - 36. Merriam, S. B. (1988). Case study research in education. San Francisco, USA: Jossey-Bass.

Ministry of Education (MOE). (2003). Thailand Kindergarten Curriculum. Bangkok, Thailand: External Relations Division, Office of the Performance Secretary. (in Thai) 